\title{
Practitioner and Faculty Perspectives on the Career Preparation Of Entry-Level Public Accountants
}

\author{
${ }^{1}$ Kathryn Simms and ${ }^{2}$ Enrique Zapatero \\ ${ }^{1}$ Department Scientist, The Research Center, Chesapeake, VA 23320, Norfolk \\ ${ }^{2}$ Department of Accountancy Finance and Information Management, \\ Norfolk State University, 700 Park Ave, Norfolk, VA 23504, Norfolk
}

\begin{abstract}
Entry-level public accountants in the U.S. must satisfy a litany of historically unparalleled requirements and demands. This unique set of challenges calls forth new questions about how effectively entry-level accountants are navigating the divide between their conceptual educations and the practical rigors of public practice. To examine these questions, we relied on qualitative analysis predicated on a theoretical framework of constructivism and systems theory. Our study confirmed practitioners' perceptions about the preparation of entry-level accountants that have been documented for nearly a hundred years: Entry-level accountants' shortcomings often include written and oral communications skills, interpersonal skills and critical thinking skills. However, what is unique to this study is that we also considered faculty perspectives. Faculty concurred with practitioners' perspectives on entry-level accountants' strengths and weaknesses-noting considerable growth in most problem areas over the college years. Practitioners and faculty also largely agreed about the pathway to successful and unsuccessful careers in public accounting. We suggest that continuing the historical perspective of extreme separation between academia and the business world is not particularly beneficial to the career preparation of junior accountants. Rather, we recommend that viewing accounting faculty and practitioners as part of the same continuum is likely to be more advantageous to the preparation of entry-level accountants and to the profession as a whole. We also conclude that differences in faculty and practitioner perspectives serve as checks and balances on the accounting profession-although more collaboration might facilitate greater improvements.
\end{abstract}

Keywords: History of Accounting, Accounting Education, Qualifications of Entry-Level Public Accountants, Career Development in Public Accounting

\section{INTRODUCTION}

Entry-level public accountantsin the U.S. must satisfy a litany of historically unparalleled requirements and demands. In particular, new entrants must satisfy the 150-hour rule for licensure as Certified Public Accountants (CPAs) (AICPA, 2012). This requirement presents students not only with an additional year of study, but also with the challenge of paying for that year during a recessionary time marked by rapidly escalating college tuitions (O'Leary, 2010). Entry-level accountants must assimilate and synthesize Generally Accepted
Accounting Principles (GAAP) derived from over 2,000 sometimes contradictory pronouncements (Kieso et al., 2011). They must grapple with sometimes divergent sets of accounting and auditing standards-given the tug of war between the Financial Accounting Standards Board (FASB) and the looming adoption of International Accounting Standards (IAS) and the tension between the United States Public Company Accounting Oversight Board (PCAOB) and the American Institute for Public Certified Accountants (AIPCA). Furthermore, new entrants must master the arduous requirements of Sarbanes-Oxley (SOX) (Sneller and Langendijk, 2007).

Corresponding Author: Kathryn Simms, Department Scientist, The Research Center, Chesapeake, VA 23320, Norfolk 
This unique set of challenges calls forth new questions about how effectively entry-level accountants are navigating the divide between their conceptual educations and the practical rigors of public practice. Although this divide between faculty and practitioners is nearly as old as the academic discipline of accounting itself (Langenderfer, 1987; Wyhe, 2007a)-it may take on new meaning and significance in the context of modern day demands. Additionally, most practitioner-developed resources about improving the quality of accounting education were issued prior to the emergence of this newest set of challenges (AAA, 1986; AECC, 1990; Andersen et al., 1989). More recent updates (Coopers, 2003) seem to recycle old advice without providing new insights into modern challenges. Furthermore, relevant information from the academy has typically been more muted-given that this information has tended to be more independently launched and related to specific criticisms from public practice (Graves, 2004; Dosch and Wambsganss, 2006).

This study addresses these shortcomings in the extant literature by providing an appraisal of the career preparation of entry-level accountants. It considers more recent demands on entry-level accountants and it attempts to balance the perspectives of practitioners and faculty. To do so, it relies on qualitative analysis predicated on a theoretical framework of constructivism (Guba and Lincoln, 1990) and systems theory (Gharajeaghi and Ackoff, 1985). Before discussing the study itself; we place it in context by providing the reader with relevant background information through a review of the literature. This literature review describes the independent, yet sometimes commingled evolutions of U.S. accounting in higher education and in practice. Additionally, we summarize prior research on the career preparations of entry-level public accountants.

\subsection{Review of the Literature: The Evolution of Accounting Education in the US}

Prior to the introduction of accounting at the Wharton School of Finance and Economics in 1883, prospective accountants in the US learned their trade through apprenticeship-a tradition adapted from European practices (Langenderfer, 1987). Due to its novelty, accounting's position in academe was initially tenuous. Hence, the academic professorate evolved out of a quest for legitimacy and acceptance from the perspectives of what would prove to be centrifugal forces: The established academy and practicing accountants (Langenderfer, 1987; Wyhe, 2007a). In particular, accounting faculty sought respect from established disciplines in the Liberal Arts--which considered accounting to be a vocation and too practical to merit a place in higher education. In response, the accounting professorate developed a niche in the academy by deriving accounting theory. This shift away from practice culminated in a doctoral-driven, researchcentered professorate. It was spurred on specifically by the Accounting Review's emphasis on quantitative research in the 1920s (Langenderfer, 1987); the infamous Ford and Carnegie Foundation Reports that questioned the legitimacy of accounting in higher education in the 1950s (Langenderfer, 1987; Wyhe, 2007a); and subsequent events, such as the research-oriented Association to Advance Collegiate Schools of Business (AACSB)'s victory over the more practitioner-oriented AICPA in the battle to accredit U.S. accounting programs (Wyhe, 2007b).

At the same time that research solidified accounting as an academic discipline, it also eroded academic accounting's long-standing connection to practitioners. This connection was always strained, as evidenced by disdain among early practitioners, who often considered the professoriate to be failed professionals whose instruction to students needed to be discounted in order for students to prosper in the profession (Wyhe, 2007a). What has continued to unite faculty and practitioners is a struggle to develop accounting into a profession as prestigious as medicine and law. Joint influence over the CPA exam has served as the primary instrument in this struggle and serves as a main forum for interaction between academicians and practitioners (Wyhe, 2007a; 2007b).

Some evidence does suggest that the divide between academic and public practice may not be as wide in reality as it is classically perceived. Kachelmeier (2002) notes the correlation between publication success and effective teaching. He also points out the practical value of testing the empirical relevance of accounting pronouncements--as well as research's utility as a source of intellectual stimulation that prevents faculty stagnation. Additionally, Crawford (2011) provides evidence that both practitioners and faculty respect the importance of practice-given that both groups support2years of work experience as a requirement for certification. Furthermore, the academy has responded to changes in public practice by developing a more international focus in coursework (AlHashim and Weiss, 2004) and by emphasizing internal controls, fraud detection and working paper management in the aftermath of recent accounting scandals (Armitage, 2008). It is important to note that these adaptations are being developed by a professoriate that is declining in 
numbers; discouraged about the probability of earning tenure; strained by demands for greater efficiency; and less frequently in demand themselves per a review of university faculty searches (Fogary and Markarian, 2007).

\subsection{Review of the Literature: Evolution of Public Accounting as a Profession in the US}

The origins of public accounting in the U.S. were wholly inauspicious. At the end of the 19th-century, demand for accounting was weak and British accountants were in vogue, so that unemployment was commonplace among US accountants-who were all white and male through the 1950s (Dennis, 2000). The practice of accounting itself was rote, consisting of long hours of basic ticking and tying. Not surprisingly, character and professional judgment were more prized than technical skills. In fact, a high school education was the American Institute of Accountants Committee (AIAC) on Education's stated recommendation for certificationuntil at least 1945 (Edwards, 1956). Evidence of the profession's long-term emphasis on more rigorous education began to emerge about that time. For example, New York required a college degree for certification in 1938 (Edwards, 1956). Later, the AICPA advocated a post-baccalaureate education (subsequently known as the 150-hour rule) as early as the 1950s (Crawford, 2011). In addition to embracing college education outside of its realm, the profession would also insist on education within its ranks through continued professional education.

Surprisingly, accounting was born not out of free market forces, despite a clear need for auditing services (Dennis, 2000): Business transactions during the Industrial Revolution were stifled in comparison with modern times due to lack of financial disclosure. Financial secrecy was the norm and audits typically uncovered corporate malfeasance-which usually limited third-party willingness to invest in other companies. Instead of emerging as a solution to this liquidity problem, modern day accounting was stimulated by federal regulation through the Federal Income Tax in 1913 and the Excess Profits Tax in 1917 (Edwards, 1958). Cunning accountants relied on required income tax preparation as a backdoor for selling their clients other financial services. As a result, U.S. accounting expanded so that by 1928 most accountants in the United States were American, although English and Scottish influences remained.

Regulation has continued to be an impetus for growth and change in the profession. In particular, the Securities and Exchange Act of 1934 required all publicly traded companies to be audited-based on a presumption that the absence of this requirement contributed to the Depression (Edwards, 1956). Hence, the Securities and Exchange Act of 1934 greatly increased audit engagements. It also shaped the accounting industry so that some accounting firms audited SEC-registrants and others did not-signifying the genesis of a historical divide between national and local firms (Olson, 1999). Paradoxically, the Act also marked tensions within the accounting industry against too much federal oversight (Edwards, 1956), leading to attempts at self-regulation. Self-regulation itself was associated with unstable professional associations likely to collapse in times of crisis when the profession was criticized. These vanishing organizations also contributed to a trail of accounting pronouncements that rendered accounting practices more uniform, contradictory and circumvent able -all at the same time.

Although increased regulation was the normal direction for change in public accounting services, in at least one instance, decreased regulation shaped the future of the industry. More specifically, in the 1970s, the AICPA's restriction on advertising and solicitation was ruled anticompetitive under the Sherman Act (Olson, 1999). Lifting this restriction triggered bidding wars for clients, drove down audit costs and, as a result, potentially reduced audit quality. Decreased audit fees in turn generated an incentive for accounting firms to engage in more lucrative consulting engagementsleading to questions about auditor independence implicated in future audit scandals.

This interconnection between regulation, scandal and adaptation in the accounting industry cycles through the profession's history. McKesson and Robbins in 1938 was perhaps the most famous early case (Edwards, 1956). Like many scandals, it ultimately improved accounting practice by triggering confirmation of accounts receivable and inventory observation. Overtime, accounting scandals have intensified in scope and effect (e.g., ZZZZ Best, Penn Central, W.R. Grace, Sunbeam, WorldCom, Tyco and Enron) (Turner, 2006). More recent scandals have been predicated on earnings management through sham Special Purposes Entities, questionable interpretations of materiality and other practices that elevated the form of transactions over their substance. These practices have shaken the credibility of the financial markets, led to the demise of accounting giant Arthur Andersen (Krishnan and Visvanathan, 2008), triggered the passage of SOX and the formation of yet another accounting oversight body--the PCAOB. Whether the most recent cycle of accounting scandals and resulting regulation will improve the profession 
cannot be fully determined at the present time. What is more certain, though, is that these events mark the end of an era, where U.S. accounting has come full circle and is considering adopting International Accounting Standards over its own.

\subsection{Review of the Literature: Perspectives on Career Preparation}

The accounting profession's criticisms of and proposed solutions to inadequate accounting education have been remarkably stable over time-although precise descriptions and related terminologies have varied. In the 1920s, entry-level accountants were criticized for their poor technical skills (i.e., "...lacking in many of the rudiments of business arithmetic". Wyhe (2007a), communication skills and analytical skills (i.e., being "...unable to grasp simple business problems quickly "and simply "not thinking clearly" Wyhe (2007a). Critiques were similar in the 1940s with the additional conclusion that rote teaching in academe likely precipitated many of these shortcomings by rendering junior accountants unable to apply their knowledge to new situations. The AAA (1986) Bedford Report characterized the solution to these problems with knowledge application, generalization and transfer as (1) conveying to college students that they are "learning to learn" (p. 169) and (2) incorporating more problemsolving skills, class participation and research-based assignments into coursework. Additional solutions to problems with accounting education were vague: to focus more on communication skills; to provide a better understanding of the accounting profession; to require a broad-based Liberal Arts education and to increase instruction about accounting information systems.

Evidence that deficiencies in education were accountable for deficiencies in entry-level accountants rested in a broad examination of form over substance. In other words, the Bedford Report rooted its criticism in the stability of accounting curriculum--i.e., the distribution of credit hours and course titles (e.g., Introduction to Accounting, Intermediate Accounting) had not changed over time. It did not empirically substantiate academe's purported failure to adjust course content and modes of delivery. However, the Bedford Report's conclusions were echoed conceptually in the "Big 8 White Paper" (Andersen et al., 1989) and the Accounting Education Change Commission's (AECC) report on "Objectives of Education for Accountants" (AECC, 1990).

A more recent report on accounting education was empirically based (Coopers, 2003). Analyses consisted of document analysis, interviews and participant observation at nine universities classified as significant feeders of entry-level public accountants. The report did not incorporate quantitative analyses of outcome measures (e.g., proficiency measures in communication, interpersonal skills, technical skills; evidence of the relationship between these skills and advancement within profession). The Report's bulleted take-aways were consistent with historical critiques (AAA, 1986; AECC, 1990; Andersen et al., 1989; Wyhe, 2007a)-except for a conclusion that the utility of Master's degree programs, besides Master's in Taxation programs, is uncertain. This conclusion, based on a sample of four Master's degree programs, was drawn due to Master's programs being too specialized, rather than being broad-based-despite evidence that Master's students demonstrated greater maturity, internship experience and skill in applying accounting principles broadly.

Absent from the take-aways was information about the substantial variability within sampled accounting programs. Discussed elsewhere within the 48-page report, this variability might seem to preclude generalizations about accounting education as a whole:

"That said, we would be remiss if we did not note that there was nearly as much variance within programsin terms of the emphasis on technical training-as there was across the programs we studied. Significantly, the pattern of considerable within-program variance was echoed across all six of the curriculum features we identified at all nine programs".

Additionally the report's main conclusions failed to contextualize and emphasize the achievements of accounting education within higher education, despite an aside that stated.

"Indeed, it is our interpretation-the senior researcher on this study having studied undergraduate and graduate change and innovation across many disciplines and fields of study for nearly three decades-that there is considerably more meaningful change and innovation taking place within undergraduate accounting education than many other fields of study, at least in the nine programs we studied.

Evidence of faculty perspectives on the preparation of entry-level accountants is less abundant, launched more independently, typically briefer and generally directed to specific criticisms raised by accounting professionals. For example, Graves (2004) responded to Coopers (2003) by defending Master's of Accountancy programs as offering the potential for broad study of accounting theory, ethics and relevance to society as a whole. Additionally, Dosch and Wambsganss (2006) replied to allegations that the professoriate had perpetuated recent accounting scandals via the classical fraud triangle (i.e., 
academia neither instructs, incentivizes, nor rationalizes unethical choices).

Broad-based academic discussions about the quality of the profession's induction of entry-level accountants are absent from the literature. A consideration of relevant literatures in other disciplines is also missing from both professional and academic discussions. Of particular relevance may be evidence about the problematic and difficult intellectual transitions among all college students (Arum and Roska, 2011). Additionally, in-depth consideration of classic intergenerational conflicts (Zemke et al., 1999) appears to be lacking-although Scarpati (2010) does allude to these conflicts. Additionally, neither group explicitly documents the role of student responsibility in career preparation.

\section{MATERIALS AND METHODS}

This study is a qualitative study-a method less common in accounting research and, therefore, developed from the rich qualitative traditions in other disciplines in the social sciences such as education, sociology, anthropology, psychology and human services (Patton, 2001). Qualitative research is particularly useful in advancing extant knowledge on understudied topicssuch as in the present context, where little research is available about specific differences in practitioner and faculty perspectives on the career preparation of entrylevel public accountants. Qualitative research is typically considered less generalizable than well-designed quantitative research, the norm in accounting research. However, qualitative research works (1) to generate and illuminate novel fields of inquiry relevant to future, more generalizable quantitative research and (2) to provide unique evidence about human experiences relevant to the topic of study.

\subsection{Theoretical Perspectives}

Quantitative research typically relies on an unstated post positivist paradigm (Ponterotto, 2005), where empirical evidence either corroborates or fails to corroborate research hypotheses. By contrast, in qualitative research, investigators select from a wide variety of theoretical traditions that most appropriately reflect the topic under study as well as the traditions in their academic disciplines. In fact, qualitative texts currently present nearly 20 differing research perspectives (Patton, 2001). We selected two primary theoretical traditions as being most germane to this study: constructivism and systems theory.
Constructivism abandons the notion of universal truth (Guba and Lincoln, 1990). Instead, under a constructivist framework, all perspectives are treated as equally legitimate. Our study also aligns with branches of constructivism such as constructionist (Crotty, 1998) which acknowledges the role of social and cultural interactions in generating individual-level truths. Hence, we intentionally acknowledge no single perspective on how to educate entry-level accountants as solely correct. Instead, we assert that both academic and practitioner environments have strengths and challenges that likely yield distinct, yet equally valid and valuable viewpoints on the career preparation of entry-level accountants.

Although we recognize that academic practice and professional practice diverge enough to warrant the colloquialisms "academic world" and "real world," these practices can also be viewed as components of a single system. Hence, we also selected systems theory as a theoretical lens for this study (Gharajeaghi and Ackoff, 1985). Under a systems approach, subparts of a system cannot be understood in isolation, but must be examined holistically. Consequently, in addition to acknowledging the individual truths of both practitioner and academic perspectives, we also considered it paramount to gain a better understanding of how these perspectives synergize to create the existing system of career preparation.

\subsection{Bracketing of Researcher Background}

Researcher objectivity is a basic, but typically unstated assumption of traditional quantitative research. However, in qualitative research, investigators are expected to reflect on (or bracket) their own backgrounds in terms of how their backgrounds influence study development and interpretation of study findings. It is also somewhat typical for researchers' backgrounds to be disclosed to readers. Along these lines, the first author in this study discloses that she has about 17 years of combined experience in accounting-related academic fields $(41 \%)$ and professional practice $(59 \%)$. She also holds a second $\mathrm{PhD}$ in education, which has contributed additional perspectives on career preparation and on education processes. The second author of this study discloses that he has a total of 28 years of higher education experience in accounting/information systemsrelated fields. He also holds an MBA.

\subsection{Study Design}

Well-designed quantitative research is generally conducted based on large representative samples. In contrast, sampling in qualitative research is based on purposeful sampling, a technique under which a 
relatively small number of highly informative cases are selected for in-depth analysis. In this study, we relied on criterion purposeful sampling with two sets of criterion for faculty and practitioner participants. Faculty were required both to have substantial academic experience in accounting and to have $\mathrm{PhDs}$. As a result of this criterion, we selected three $\mathrm{PhD}$-level faculty from an accredited business school in a mid-Atlantic state. These faculty members had a mean of 20 years in accounting education. The majority of these faculty members had held professional certifications for over 25 years. The sample of three accounting professionals had been in public practice for a mean of 16 years and reflected a broad range of experience levels in evaluating entrylevel staff: supervising senior, senior manager and partner. All were CPAs.

After obtaining IRB clearances from our academic institution, we obtained consent from faculty and practitioners for participation in this study. Each participant completed a brief survey about his or her academic and professional qualifications and, then, responded to a structured interview. Participants were given two options for being interviewed: (1) to participate in a recorded, one-on-one interview with one of the researchers or (2) to answer interview questions online with a brief follow-up interview with study researchers, if needed. All participants selected the second option. Furthermore, we provided each participant with a draft of our findings and requested additional comments.

Interview questions themselves were designed to capture the strengths/weaknesses and areas of improvement regarding the career preparation of entrylevel public accountants. Ten queries were constructed with slight rewordings appropriate for each participant group. Below are the structured interview questions for practitioners: (To avoid unnecessary duplication, we have omitted the adapted faculty queries):

- Describe the qualifications of typical entry-level accountants in public accounting today.

- What are the strengths of typical entry-level accountants in public accounting today? Weaknesses?

- What skills and traits do accountants need in an entry-level, public accounting position?

- What are some of the signs that an entry-level accountant is "in trouble" in early stages of his or her career? How often would you say that entrylevel accountants are able to overcome these shortcomings? How do they do so?
- What skills and traits do entry-level accountants in public accounting need for advancement to management? To partner? What percentage of entrylevel accountants do you think typically have these traits and skills? How do you think they go about developing or could go about developing these skills and traits if they do not already have them?

- If you could make any suggestions you wanted to accounting faculty to improve the quality of entrylevel accountants what would these suggestions be?

- For whatever reason, public accounting firms have often been considered to be revolving doors in terms of dismissing junior accountants. What is your perspective on this? Please explain.

- What do you foresee regarding the future need for college preparation of entry-level public accountants?

- Would you advise your own child to go into public accounting today? Please explain.

- Is there anything else you can tell me to help me understand the current state of preparation of entrylevel accountants in public accounting?

Following interviews with participants, we created three datasets: one containing data on participant's professional backgrounds and two datasets with coded transcripts of the structured interviews. Each researcher coded the transcriptions independently without mutual discussion from three perspectives: similarities in practitioner and faculty responses; differences in responses; and uniqueness in each set of responses. After we finalized our individual coding, we evaluated our results jointly for consensus. Due to the novelty of this line of inquiry and in alignment with the central tenants of constructivism, we also preserved differences in our coding as a possible relevant direction for future research.

\section{RESULTS}

\subsection{Practitioner Viewpoints}

On the whole, practitioners tended to emphasize personality traits or personal characteristics as primary indicators that students were qualified to work in public accounting. These qualifications included intelligence, having strong work ethic, understanding how to work as a team, integrity and self-sacrifice (i.e., putting the client first). One practitioner also stated: "We are not expecting for our staff to have the
answer but rather [to be able to] learn how to get
the answer. We need them to realize that in a free 
market, clients can take their business elsewhere. I need people that want to be at work on time and without daily drama".

In response to questions about basic qualification of entry-level accountants, there was somewhat of a tendency to depersonalize entry-level accountants as "raw materials that must be formed into incomeproducing assets".

Only one practitioner interviewed stated that earning a college degree was the main qualifier for an entry-level practitioner. This practitioner, however, restricted such degree to being one earned "from a respected university". Another practitioner explicitly rejected degree completion as being anything more than a superficial qualification for entering public accounting, stating that degrees are merely indications of students' abilities to learn. At several points during our interviews, statements were made that an accounting degree was not even especially beneficial during the initial stages of public practice. However, internship experience was regarded as potentially valuable.

At other points during the interviews, practitioners were mainly complimentary of entry-level accountants' academic preparation on the whole--although practitioners stated that they observed substantial variability in career preparedness. At these times, practitioners stressed the importance of entry-level accountants having technical skills, but these practitioners sometimes appeared to speak about technical skills in a limited fashion (e.g., basic understanding of debits and credits).

They also cited opportunities for improvements in students' academic preparations. These opportunities included:

- Working to improve interpersonal skills (e.g., teaching students how to make better judgments about whether to communicate with clients by email or in person)

- Improving written communication and analytical reasoning skills (e.g., documenting the logic of assessments of materiality)

They also suggested increasing collaboration between practitioners and faculty in terms of improving student instruction. These potential collaborations ranged from specific weaknesses to more broad conceptual concerns. For example, one practitioner stated that practitionerfaculty collaborations would probably facilitate a better understanding of the preparation of statements of cash flows. Additionally, professionals believed that collaborations could help students develop clearer perceptions about auditing in general. One practitioner stated, "For instance, why discuss a qualified opinion when in practice, they are really never given? I did not understand this until I worked in public accounting".

Practitioners also recounted problems with work ethic among some junior accountants. They also described a downward spiraling career trajectory when entry-level accountants lacked technical skills; could not understand "the big picture;" and could not develop into independent thinkers, but asked the same questions repeatedly. In these cases, junior accountants often lost management confidence and were no longer assigned work to do-a situation that typically leads to termination.

It was somewhat unclear from our interviews how many junior accountants actually experience this downward career trajectory. One practitioner suggested that a 3-year tenure among junior public accountants was the historical objective of public accounting firms; another stated 60 to $70 \%$ of first-year associates depart from public accounting. There was a lack of consensus about the typical reasons for these departures. One practitioner stated that most entry-level employees did understand the demands of public practice, but tended to leave due to career disappointment, other opportunities, or to life-changing events. Another practitioner stated that these employees exited from public firms because they did not understand the work commitment required in advance; however, these employees did tend to leave public accounting by choice. The third practitioner explicitly affirmed the existence of a revolving door for junior level accountants--stating that firms were beginning to realize that this practice was counterproductive.

Practitioners also discussed the likelihood of promotion for more successful junior level-accountants. In sum, they stated that promotion is based on the needs of the firm and whether junior-level accountants have prerequisite skill set (i.e., technical skills, communication skills and interpersonal skills). Such accountants must also have been willing to make substantial personal sacrifices for their careers. Many candidates for promotion were reported to simply burnout. No practitioners perceived a college education as the main factor that prepared most junior accountants for advancement. Rather, on the job training and experience served as the main vehicles for advancement.

\subsection{Faculty Perceptions}

In contrast to practitioners, faculty emphasized satisfying academic requirements as the main 
qualification for entering public accounting. They stressed the need to fulfill credit-hour requirements in accounting as well as to complete specific curriculum requirements. Faculty also focused on the importance of truly understanding course materials, rather than simply completing an accounting curriculum. They emphasized basic computer skills, information gathering skills and information evaluation skills as additional qualifications for entry-level public accountants.

In response to other questions, they stressed technical skills as being crucial for entry-level accountants. However, they also recognized the need for entry-level accountants to have the chief prerequisite skills emphasized by practitioners. In particular, they cited critical thinking, good communication skills, work ethic and motivation, professional ethics and a commitment to professional development (i.e., a growth mind-set).

When faculty were asked for more detail about whether they typically observe growth during students' college years, faculty stated that students' written communication skills do grow significantly throughout their educations. Faculty also affirmed that they do discuss professional conduct and the structure of public accounting firms in their classes. When asked about whether they explicitly assist students overcome perceptions of entitlement, one faculty member responded:

"I do not discuss entitlement issues [in class] because they do not relate to accounting. I only discuss political issues that directly affect the accounting profession such as why SarbanesOxley came about".

In terms of strengthening critical thinking skills, faculty recognized a need to bolster academic instruction as accounting practices become more complex. One stated:

\begin{abstract}
"There has to be more emphasis placed on critical thinking skills. There are too many problems that are highly unstructured and do not have a clear solution. Accounting programs create the illusion of 'the right solution' among accounting students. Sometimes, there are problems that have more than one simple solution and this is when critical thinking skills become so crucial".
\end{abstract}

Faculty largely echoed professionals' perspectives on problems with entry-level public accountants. They recognized that technical skills were typically the strongest components of entry-level accountants' skill sets and those students' greatest difficulties revolved around higher order reasoning skills and oral and written communications skills. They acknowledged students' perceptions of entitlement as much-if not slightly morethan practitioners did. Furthermore, they all articulated how these weaknesses could culminate in a path to termination for junior accountants. In particular, they foresaw this path as being denoted by a failure to be appropriately self-reliant (i.e., not recognizing when to ask for help and when to persist in figuring out solutions independently). Faculty also recognized the short-time frame that entry-level practitioners have to prove themselves in public accounting-with most affirming their belief in what is typically referred to as a revolving door in public accounting. However, they tended not to hold accounting firms responsible for the terminations, but to hold entry-level accountants responsible for not having obtained adequate skills. A dissenting faculty member cited natural market forces as being responsible for the junior-level accountants' departures: In other words, firms simply require fewer managers and partners than they do junior accountants.

Faculty also shared most of practitioners' perspectives on criteria for advancement in public accounting-particularly noting the need for growth in interpersonal skills and increased technical skills. Interestingly, only faculty acknowledged the need to develop salesmanship as part of the path toward advancement. They further addressed learning to compete appropriately with other junior level accountants; they also spoke about the need to develop professional networks and to seek a mentor-all factors also omitted by practitioners. In fact, faculty felt so strongly about the need for mentorship in public accounting, that developing explicit mentorship programs was their primary suggestion for change within public accounting firms. Unlike some practitioners who were somewhat critical of business schools, faculties were not critical of public accounting firms per se. Instead, they stressed that problems with junior accountants rested at the individual level with the junior accountant.

\section{DISCUSSION}

On one level, this study corroborates extant literature (AAA, 1986; AECC, 1990; Andersen et al., 1989; Coopers, 2003; Wyhe, 2007a). It finds that communication skills, interpersonal skills and analytical reasoning skills are chief shortcomings of entry-level public accountants. At the same time, our results imply serious questions about whether accounting education is the main culprit in perpetuating these shortcomings. In 
particular, accounting faculty explicitly recognized these same shortcomings among the students they teach and they pointed to significant improvements in these problem-areas during students' college years. Hence, although practitioners'viewed entry-level accountants as "raw materials," it also may be beneficial to recognize that faculty observed entry-level public accountants in an even "rawer" state and facilitated growth in their students. This finding leads to the main conclusion of our study: Although academic and professional accounting have long been conceptualized as being separate worlds, re-conceptualizing academic and public practice as part of the same continuum is likely to yield more accurate evaluations of the career preparedness of entry-level accountants. We also suggest that this viewpoint is more likely to provide effective methods for improving career preparedness of entry-level accountants.

Additionally, taking a step back from analogies that depersonalize entry-level accountants as assets may be instructive-despite the fact that such analogies have some logic in service-based businesses. We suggest developing an alternative perspective because of substantial consistency between descriptions of entrylevel accountants and fundamental theories of growth and human development (Berk, 2009). It may be constructive to consider how to address induction into public practice based on young adults' natural pathway of maturation and brain development, rather than to focus on specific shortcomings. We suggest this approach especially in light of about a hundred years of documentation of entry-level accountants' exhibiting the same weaknesses year after year.

At the same time, this study does offer important insights about how to improve accounting education. At a fundamental level, practitioners and faculty might benefit from considering each other's perspectives on the main qualifications of entry-level accountants. Practitioners appeared to have more of a trait-orientation (e.g., being a hard-worker) and faculty were focused on qualifications mainly connected with eligibility to sit for the CPA exam--a baseline requirement for public practice. On some levels, academics and practitioners have synthesized their differing viewpoints because they readily affirm the importance of both technical abilities and personal traits.

However, the disparity in their priorities appears to be of considerable importance. Faculty clearly thought some discussions about professional behaviors in the classroom were appropriate; however, they tended to believe that accounting was more about content knowledge. Furthermore, some discussions-such as explicit discussions of perception of entitlement--were not considered to be particularly appropriate for academic classrooms. As long as these perceptions hold among academicians, practitioners' expectations about the career preparation of junior accountants are not likely to be satisfied. Three solutions appear possible: Add coursework about professional behavior to college curricula; incorporate training sessions about professional conduct when new employees are hired in public accounting; or adjust both college curricula and professional induction programs to provide specific instruction about professional behavior.

We posit that learning appropriate professional behavior and interpersonal skills is a long process, so that the third solution is likely to be the most effective. We also suggest that difficulties adapting to cultures in public accounting may be greater than either faculty or practitioners have indicated. Only about 7\% of the U.S. population has a master's degree (CE, 2011) -which is the closest comparison we can draw between the 5-year requirement in public accounting and degree attainment among the entire U.S. population. Yet, a very high percentage (i.e., estimated as 60 to $70 \%$ in this study) of entry-level accountants do not persist beyond entry-level employment in public accounting. This percentage is disconcerting-given that these entry-level public accountants have already demonstrated high levels of persistence in what is widely considered to be the most difficult career path in a challenging major. We suggest that these findings indicate considerable need for improvement in the transition from college to entry-level public practice. We do not, however, discount the legitimacy of alternative explanations that participants put forth, which somewhat dilute our concerns (e.g., there are simply relatively few management positions).

Our study also indicates that faculty-practitioner collaboration may improve accounting instruction pertaining to technical skills. We point in particular to the suggestion that students would benefit from practitioner input about how to prepare Statements of Cash Flows. That practitioners indicate significant shortcomings in entry-level accountants' ability to create a basic accounting statement is of significant concern. We believe this observation is particularly worthy of further investigation and adaptation in instruction.

We question, though, whether some of professionals' criticism of accounting instruction might actually indicate the need to reconsider aspects of accounting practice. More specifically, we had mixed reactions about the suggestion that qualified audit opinions should be omitted from academic instruction. On one hand, if 
qualified audit opinions are not issued, then why do regulating agencies continue to put them forth as an option? Possibly, these opinions should be removed from professional guidelines as well as from classroom instruction. On the other hand, could the failure to issue qualified statements indicate another problem? In particular, given the profession's long-history of scandal and conceding to client pressures, does failure to issue this type of audit opinion highlight a vulnerability in public practice? This study was not designed to answer these questions, but we do conclude that treating public and academia as a continuum is more likely to foster the collaborations necessary to answer these questions as well as to improve both practice and academia in general.

In a sense, such a collaborative continuum offers both accounting practitioners and academia an opportunity to "audit" one another with a great deal of actual independence. Just as practitioners' observations suggested improvements in instruction, faculty observations appeared to offer fuller insight about public practice. For example, faculty appeared to be much more forthcoming about the connection between salesmanship and advancement in public accounting. Hence, participants who are removed from practice may have the potential to observe what the profession sometimes might overlook about itself. Such observations from faculty have the potential to strengthen both academic and continuing professional instruction as well as could influence which students are recruited as accounting majorsin the first place. Many of the "wrong" students and entry-level accountants may self-select currently, given that conventional wisdom depicts accounting as an optimal career choice for persons who have few interpersonal skills, especially not salesmanship.

\section{CONCLUSION}

Despite demands on entry-level public accountants, nearly everyone we interviewed indicated that they would recommend public accounting as a career path to their own child. Little variability existed in the main rational for doing so: Public accounting is a good career because accountants are highly paid. A few participants offered supplemental perspectives such as public accounting is an ideal career because public accountants are well-perceived by the public and public accounting can serve as a route to other highly paid professions. One participant did dissent stating that there was too much pressure and overtime and that, consequently, he or she would not suggest public accounting as a career.
Although it would be unrealistic to think that all pressures in public accounting could ever be eliminated, we suggest that a more holistic, collaborative perspective of public and academic practices may work to address such concerns about the high levels of stress to which this participant and most other participants referred throughout their interviews. From a much larger perspective, we conclude that improving the career induction process in public accounting is a crucial objective. The chances of failure are extremely high and most entry-level public accountants probably do not have a parent or mentor in the profession to guide their way.

\section{ACKNOWLEDGMENT}

We would like to acknowledge Donald G. Simms, MBA and Sara Bock, BA for their helpful comments and editorial assistance. We also thank Ms. Lauren Smith for her administrative assistance.

At the time we conducted this study, Kathryn Simms received her salaries from Title III \#2140053: Strengthening Research Capacity in the College of Liberal Arts (9-2010 to 9-2012). However, this project was not specifically funded by that grant.

\section{REFERENCES}

AAA, 1986. Committee on the future structure, content and scope of accounting education (The Bedford Committee), Future accounting education: Preparing for the expanding profession. Issues Account. Edu., 1: 168-195.

AECC, 1990. Objectives of education for accountants: Position statement number one. Issues Account. Educ., 5: 307-312.

AICPA, 2012. 150 Hour requirement for obtaining CPA certification. AICPA.

AlHashim, D.D. and E.J. Weiss, 2004. Recent developments in accounting education and the future of the AICPA 150-hour requirement. Int. J. Commerce Manage., 14: 19-27. DOI: 10.1108/10569210480000171

Andersen, C., C. Young, L. Deloitte, H. Sells and E.W. Peat et al., 1989. Perspectives on education: Capabilities for success in the accounting profession. AAA, New York.

Armitage, J., 2008. Changes in the importance of topics in auditing education: 2000-2005. Manager. Audit J., 23: 935-959. DOI: 10.1108/02686900810908463 
Arum, R. and J. Roksa, 2011. Academically Adrift: Limited Learning on College Campuses. 1st Edn., University of Chicago Press, Chicago, ISBN-10: 0226028550 , pp: 272.

Berk, L.E., 2009. Development Through the Lifespan. 5th Ed. Pearson Prentice Hall, Upper Saddle River, N.J., ISBN-10: 0205687938, pp: 667.

CE, 2011. National center for education statistics.

Coopers, P., 2003. Educating for the public trust: The PricewaterhouseCoopers position on accounting education. PricewaterhouseCoopers, New York.

Crawford, D.L., 2011. Practitioner and educator preferences regarding accounting curriculum meeting the 150-hour requirement. Acad. Educ. Leadership J., 15: 47-66.

Crotty, M., 1998. The Foundations of Social Research: Meaning and Perspective in the Research Process. 1st Edn., SAGE Publications, London, ISBN-10: 0761961062, pp: 256.

Dennis, A., 2000. No one stands still in public accounting: The CPA firm in 1900, 1950 and 2000. J. Accountancy, 189: 66-74.

Dosch, R.J. and J.R. Wambsganss, 2006. The blame game: Accounting education is not alone. J. Educ. Bus., 81: 250-254. DOI: 10.3200/JOEB.81.5.250-254

Edwards, J.D., 1956. Public accounting in the United States from 1928 to 1951. Bus. History Rev., 30: 444-471. DOI: $10.2307 / 3111716$

Edwards, J.D., 1958. Public accounting in the United States from 1913 to 1928 . Bus. History Rev., 32: 74101. DOI: $10.2307 / 3111900$

Fogary, T.J. and G. Markarian, 2007. An empirical assessment of the rise and fall of accounting as an academic discipline. Issues Account. Educ., 22: 137161. DOI: 10.2308 /iace.2007.22.2.137

Gharajeaghi, J. and R.L. Ackoff, 1985. Toward systemic education of systems scientists. Syst. Res. Behav. Sci., 2: 21-27. DOI: 10.1002/sres.3850020105

Graves, O.F., 2004. A dialogue on accounting education. CPA J., 74: 14.

Guba, E. and Y. Lincoln, 1990. Can there be a human science. Person-Centered Rev., 5: 130-154.

Kachelmeier, S.J., 2002. In defense of accounting education. CPA J., 72: 34-38.

Kieso, D.E., J.J. Weygandt and T.D. Warfield, 2011. Intermediate Accounting. 14th Edn., Wiley, Hoboken, N.J., ISBN-10: 0470587237, pp: 1640.
Krishnan, G. and G. Visvanathan, 2008. Was Arthur Anderson different? Further evidence on earnings management by clients of Arthur Andersen. Int. J. Disclosure Governance, 5: 36-47.

Langenderfer, H.Q., 1987. Accounting Education's History-A 100-Year Search for Identity. J. Accountancy, 163: 302-331.

O'Leary, B., 2010. Tuition over time, 1999 to 2010. The Chronicle of Higher Education.

Olson, W.E., 1999. The accounting profession in the 20th century. CPA J., 69: 28-33.

Patton, M.Q., 2001. Qualitative Research and Evaluation Methods. 3rd Edn., SAGE Publications, Thousand Oaks, C.A., ISBN-10: 0761919716, pp: 688.

Ponterotto, J.G., 2005. Qualitative research in counseling psychology: A primer on research paradigms and philosophy of science. J. Counsel. Psychol., 52: 126136. DOI: $10.1037 / 0022-0167.52 .2 .126$

Scarpati, S., 2010. Developments in accounting education. CPA J., 80: 10-11.

Sneller, L. and H. Langendijk, 2007. Sarbanes Oxley Section 404 Costs of Compliance: A case study. Corporate Governance: Int. Rev., 15: 101-111. DOI: 10.1111/j.1467-8683.2007.00547.x

Turner, L.E., 2006. Learning from accounting history: Will we get it right this time? Issues Account. Educ., 21: 383-407. DOI: 10.2308/iace.2006.21.4.383

Wyhe, G.V., 2007a. A history of U.S. higher education in accounting, Part I: Situating accounting within the academy. Issues Account. Educ., 22: 163-181. DOI: 10.2308/iace.2007.22.2.163

Wyhe, G.V., 2007b. A history of U.S. higher education in accounting, part II: Reforming accounting within the academy. Issues Account. Educ., 22: 481-501. DOI: 10.2308 /iace.2007.22.3.481

Zemke, R., C. Raines and B. Filipczak, 1999. Generations at Work: Managing the Clash of Veterans, Boomers, Xers and Nexters in Your Workplace. 1st Edn., American Management Association, New York, ISBN-10: 0814404804, pp: 288. 